\title{
E-DEMOCRACY IN UKRAINE: CONDITION AND DEVELOPMENT TAKING INTO ACCOUNT EUROPEAN EXPERIENCE
}

\author{
Yanis Yansons \\ Department of the Parliamentary and Political Management \\ National Academy for Public Administration under the President of Ukraine \\ 20 Antona Tsedika str., Kyiv, Ukraine, 03057 \\ yan.yansons@gmail.com
}

Abstract

The work analyzes the mechanism of legal support of e-democracy development in Ukraine and European Union in a part of formation and implementation of its tools. A position of central executive authorities in Ukraine in the context of e-democracy development is considered.

The Ukrainian legislative base of formation and realization of e-democracy tools have been studied, and ones, considered priority in the aspect of their legal support and implementation level, have been separated. These e-democracy tools in Ukraine include: e-consulting, e-petitions, e-appeal, participation budgets (public budgets).

The analysis of e-democracy tools, offered and implemented in the EU countries allowed to establish a series of them, needed additional attention from both state authorities of Ukraine and Ukrainian publicity. These tools include: e-voting, e-referendum, e-plebiscites, and e-election process totally.

Based on comparison analysis of using e-democracy tools in Ukraine and EU, there have been separated obstacles on the way of potential improvement of the national legal mechanism of e-democracy development as to its tools usage at the national, regional and local levels. The main ones are: imperfection of resource provision of the development legal mechanism; absence of an integral idea of the development strategy of e-democracy as an institution in the state; predominance of e-services automation development over development of tools of active involvement of citizens in participation in the public-political life of the country.

Recommendations for public authorities as to improvement of the existent legal mechanism of implementation, use and development of e-democracy tools in a part of development of a series of strategic documents that must fix the priority of e-democracy development, its resource support; comprehensive support to public initiatives as to implementation and development of e-democracy and e-participation tools and so on, have been substantiated.

Keywords: public administration, mechanism of public administration, e-democracy, tools of e-democracy.

DOI: $10.21303 / 2504-5571.2020 .001541$

\section{Introduction}

The proper level of e-democracy is one of aims of digital society formation. Its realization takes place also by using its tools, directed on increasing, first of all, the level of public participation in the political life of a country. The notion "e-democracy tools" is defined in the Conception of e-democracy development in Ukraine [1], they are "means for providing formation and realization of a state policy, self-government development by using information-communication technologies in democratic processes". Success of e-democracy tools formation and implementation depends on proper functioning of the totality of interconnected e-democracy mechanisms (legal, organizational, financial and so on). The practices of foreign countries indicate that general regulation of e-democracy development in executive authorities is relied on the profile ministry or another central body of executive power with the correspondent fixation of priority directions of its development in the legislation, alongside with it, in managing conceptual documents of the Government. In Ukraine such body is the Ministry of digital transformation, which main aims are defined as: to 
digitalize 100 of public services, to add $100 \%$ of places to mobile connection and Internet, to teach $6 \mathrm{mln}$ of Ukrainians basic digital skills, to increase a share of IT in Ukrainian GDP up to $10 \%$ and make $100 \%$ of state services online [2].

The program of Government activity No. 471 of 12.06 .2020 [3] determines the following key directions for the digital Ministry:

1) development of administrative services and their digitalization;

2) society informatization;

3) favoring IT-business development;

4) digital literacy of the population and so on.

The development of e-democracy tools, especially creation of an online-platform for interaction between executive authorities and civic society institutions, support of the e-voting mechanism at forming public councils at central and local executive authorities. One of 10 priority tasks of the digital Ministry, visually demonstrating the executive power attitude to the development of e-democracy in Ukraine, was included. It distinctly separates current problems that are in paying not enough attention to questions of e-democracy formation and motivates to studying ways of its development mechanisms formation and improvement.

The problem of e-democracy development is also actualized by the fact that a series of conceptual and strategic documents on this topic finish their action in 2020, so new revisions of these acts are needed for providing the continuous sustainable development of the studied field, namely: the development Strategy of informational society in Ukraine, adopted by the resolution of the Cabinet of Ministries of Ukraine No. 386-p of 15.05 .2013 (till 2020); The National Strategy for favoring the development of civic society in Ukraine for 2016-2020, ratified by the Order of the President of Ukraine No. 68/2016 of 26.02.2016 (must be finished in 2020); The Conception of e-democracy development in Ukraine and the plan of arrangements as to its realization, ratified by the resolution of the Cabinet of Ministries of Ukraine No. 797-p of 08.11.2017, with changes of 05.02.2020 (till 2020); The Conception of e-government development in Ukraine, ratified by the resolution of the Cabinet of Ministries of Ukraine No. 649-p. of 20.09.2017 with changes of 05.02.2020, (realization of arrangements is planned till 2020); the Conception of digital economy and society development in Ukraine for 2018-2020, ratified by the resolution of the Cabinet of Ministries of Ukraine No. 67-p of 17.01.2018, with changes of 04.12.2019 (till 2020), and so on.

Problems of e-democracy development and implementation are considered by foreign and Ukrainian scientists.

Theoretical studies on problems of state government informatization and e-democracy are reflected in works by D. Fux, M. Kaaze. These scientists elaborated questions of the direct democracy development conception. From their point of view, the effective development of classic democracy is possible in network interaction between citizens, organizations and institutions with using e-communication systems that will evolve in e-democracy.

A. Etzioni and R. Reintgold in their turn studied problems of e-democracy development, observing communitarian approach principles. Practical aspects of e-democracy and its tools implementation are studied by G. Aichholzer and G. Rose.

Among native scientists, B. Zhylyaev, A. Semenchenko, V. Dreshpak study problems of terminology and stages of e-democracy, e-government, improvement of public administration mechanisms of e-democracy development, implementation of the European legislation to the Ukrainian one in the sphere of e-democracy [4].

N. Hrytsiak, S. Solovjev pay attention to studies of e-democracy development under conditions of digital transformations, use of information-communication technologies in state government, problems of theoretical-methodological principles of e-democracy tools and mechanisms' development, formation and implementation [5].

At the same time the problem of legal mechanism of public administration of e-democracy development in a part of e-tools improvement needs additional attention and has both practical and theoretical importance, taking into account the necessity to modernize the existing legislation. 
Aim of the study was to study the implementation and use of e-democracy tools in Ukraine and EU, to form, based on it, scientifically substantiated recommendations for authorities of Ukraine as to improvement of the legal mechanism of e-democracy tools realization.

\section{Legislation for tools of the e-democracy}

A motive force of e-democracy is the convergence of mechanisms of traditional democracy and possibilities of information-communication technologies. But any improvements in only technical aspect, without principal changes in the state policy of communication with citizens, democratization of public life in whole, active position of citizens, development of civic and information society, are not able to provide proper development and to strengthen democracy, democratic institutions. Introduction of technological aspects in democratic processes is aimed not only at widening possibilities, available to traditional democratic processes and to involve as more as possible conscious society representatives in these processes. At that, democratic values, law superiority and protection of human rights that in their turn must be combined with a technological component, must be basic.

A series of international conceptual documents contains instructions as to the use of concrete tools for developing e-democracy. Thus, Recommendations of the Committee of Ministries of the European council [6] define e-democracy tools, based on existent problems, namely low presence indices at elections, legitimacy level decrease, increase of gaps between state power and publicity, decrease of youth's interest in political processes, insufficient transparency in information and processes and so on. For solving these problems, it is offered to use e-solutions as e-participation, e-parliament, e-appeals, e-consulting, e-forums, e-initiatives. At the same time, it is noted that:

- the choice of concrete tools must reflect democratic, humanitarian, social, ethnic and cultural values;

- e-democracy must take into account realities of today information and communication society and give tools, similar to ones, used by people in everyday life;

- e-democracy tools must provide citizens' access to participation in the universal, continuous democratic processes, which must be twenty-four-hour at any place;

- continuous learning of skills, necessary for using e-democracy tools, must be offered by public educational institutions and employers, including also the form of e-learning for users.

At the national level the list of priority e-democracy tools is defined in such legislative acts as: the resolution of the Cabinet of Ministries of Ukraine No. 259-p. of 05.05.2003 "On adoption of the Conception of formation of the system of national e-information resources"; the resolution of the Cabinet of Ministries of Ukraine No. 649-p. of 20.09.2017 "On approval of the Conception of e-government development in Ukraine"; the Order of the President of Ukraine No. 683/2002 of 01.08.2002 "On additional arrangements as to providing activity transparency of state authorities"; the resolution of the Cabinet of Ministries of Ukraine No. 1302 of 29.08.2002 "On arrangements as to further provision of activity transparency of executive authorities" with changes of 05.02.2020; the resolution of the Cabinet of Ministries of Ukraine No. 386-p of 15.05.2013 "On approval of the development Strategy of information society in Ukraine"; the resolution of the Cabinet of Ministries of Ukraine No. 797-p of 08.11.2017 "On the Conception of e-democracy development in Ukraine and the plan of arrangements as to its realization" with changes of 05.02.2020; the resolution of the Cabinet of Ministries of Ukraine No. 67-p of 17.01.2018 "On the Conception of digital economy and society in Ukraine for 2018-2020”, with changes of 04.12.2019.

It is defined in the Conception of e-democracy development in Ukraine that "the most spread e-democracy tools, used for today in Ukraine at both national and local level, are e-consulting, e-petitions, e-appeals, participation budgets (public budgets). There is underlined the urgency of creation of resources for promulgating datasets as open ones, including at e-platforms, for example, "Civic society and power", "Smart city" or "Unitary system of local petitions", combining several e-participation tools".

Based on studying the aforesaid conceptual and strategic documents, the author came to a conclusion as to the absence of mutual coordination of the abovementioned documents in a part of systematization and priority of e-democracy tools. At the same time enough attention is paid to 
such e-democracy tools as: e-consulting, e-petitions, e-appeals, "open budget" (public budget). Not enough attention is paid to: e-voting, e-referendum, e-plebiscites, and e-election process totally. It is also noted in the Report about e-democracy tools use by state and local authorities of the State statistical service for 2019 [8], that main e-democracy tools for power authorities are: e-consulting, e-petitions, e-appeals, "open budget" (public budget). Other tools were not used during 2019 by power authorities.

All this testifies that for today authorities have no budgetary resources for e-democracy tools development, motivation resources are enough for supporting already realized ones, and the level of digital literacy and education of state officers doesn't allow to develop e-democracy tools properly. The analysis of statistical data of the "Report about e-democracy tools use by state and local authorities" of the State statistical service for 2019 allowed to separate such a defect as the absence of an objective system of control over data, obtained from authorities. Despite the fact that such control can be realized technically, for today information from authorities is obtained only by demand and in the polling form.

\section{Implementation of e-democracy tools in Ukraine}

According to EU experts, e-democracy tools are reflected in Recommendations of the Committee of Ministries of the European Council [6]. The comparison of the list of these tools with ones, introduced in power authorities of Ukraine, and ones, used by public organizations in Ukraine, are systematized on Fig. 1.

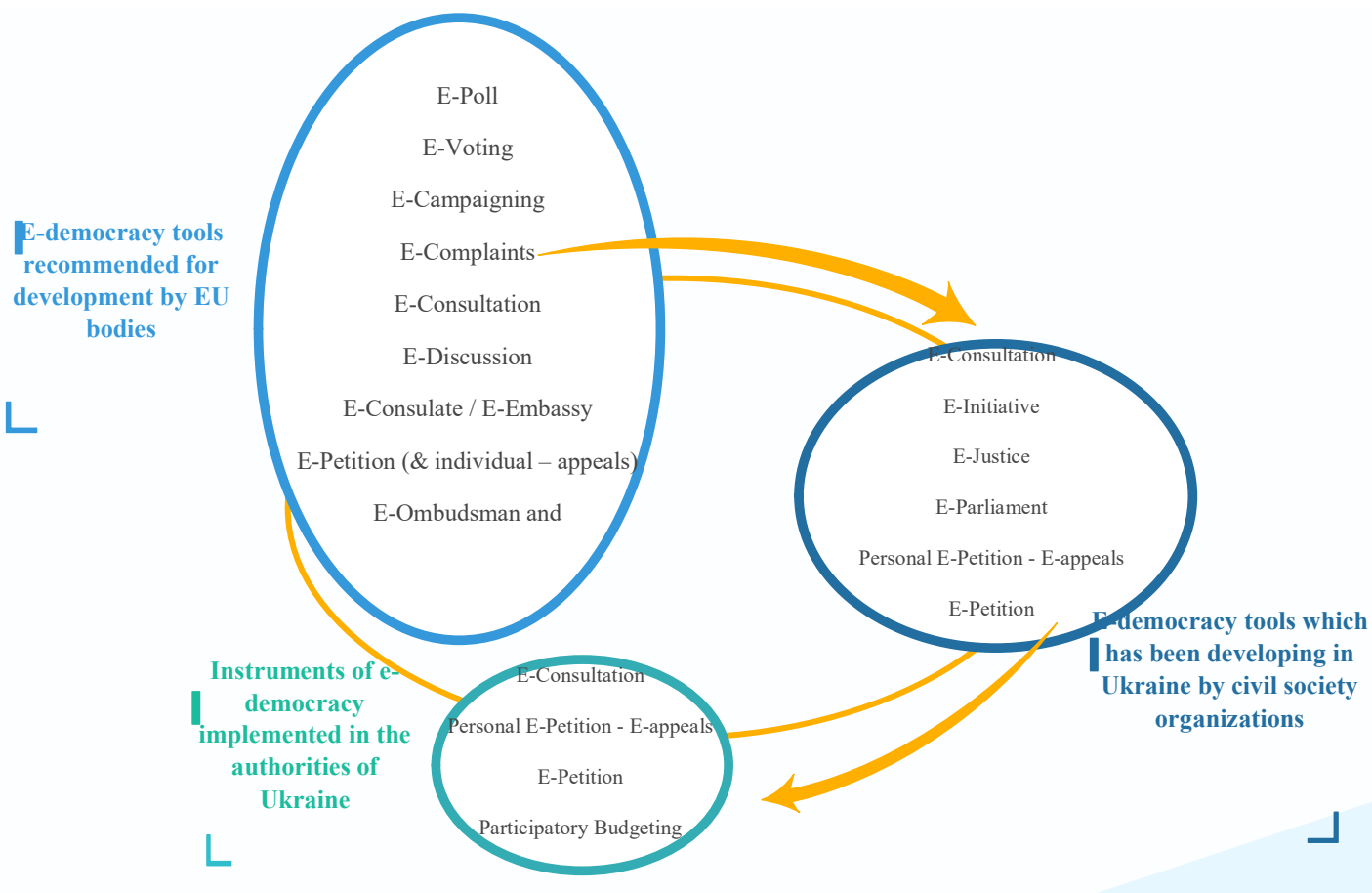

Fig. 1. E-democracy tools, recommended by EU, and their realization in Ukraine: Source: made by the author

Most e-democracy tools form and develop due to the initiative activity of public organizations, supported by European democratic movements, granting them. Most conceptual and strategic documents in the sphere of e-democracy declare the observance of European values and Recommendations, developed by the EU. Alongside with it, the main motive force remain public 
initiatives, a legal mechanism of budget financing of their activity in the sphere of e-democracy development is absent for today.

The study of e-democracy tools, realized by EU structures and their comparison with ones, introduced in Ukraine, demonstrated, that Ukraine gives advantage to the following tools: e-consulting, e-petitions, e-appeals, e-initiatives, "open budget" (public budget) (Fig. 1).

\section{Legal bases for the development of e-democracy tools in Ukraine}

According to the hierarchic structure of legal support of e-democracy development in Ukraine, the study was conducted as to the proper level of legal support of e-tools, most spread in Ukraine, which results are presented on Fig. 2.



Fig. 2. Level of legislative regulation of questions as to using e-democracy tools in Ukraine Source: made by the author

Elucidating the essence of the data, presented in Fig. 2, it must be noted, that legal development bases of e-appeals and petitions are defined in article 40 of the Constitution of Ukraine: "all have the right to send individual or collective written addresses or to address personally to state power bodies, local self-government bodies, officials of these bodies that must consider the address and give a reasonable answer in the term, established by the law".

The legal mechanism of e-appeals realization is concretized in the Laws of Ukraine "On introducing changes to the Law of Ukraine "On addresses of citizens" as to e-appeal and e-petition" (Berhovna Rada News (VRN), 2015, No. 35, art.341), “On addresses of citizens" No. 394/96-VR of 02.10.1996 with changes of 22.05.2018, BRN, 2018, No. 33, art.250, “On access to public information" No. 2939-VI of 13.01.2011 with changes of 17.06.2020, "On e-trusting services" No. 2155-VIII of 05.10.2017 with changes of 13.02.2020 and additionally regulated by a series of bylaws. Let's cite only several of them: the Order of the President of Ukraine No.109/2008 of 07.02.2008 "On first turn arrangements as to providing realization and guaranteeing of the constitutional right for addressing to state and local self-government authorities"; the Order of the President of Ukraine No.854/2004 of 31.07.2004 "On providing conditions for wider public participation in state policy formation and realization”.

The legal mechanism of e-petitions realization is reflected in the abovementioned Laws of Ukraine and the following normative documents: the Order of the President of Ukraine No.523/2015 of 28.08.2015 "On the consideration order of e-petition, addressed to the President of Ukraine"; the edict of the Head of Verhovna Rada No. 1494 of 28.10.2015 "On certain organization questions of the work on registration and maintenance of e-petitions, addressed to Verhovna Rada of Ukraine" with changes of 18.02.2016; the resolution of the Cabinet of Ministries of Ukraine No. 457 of 22.07.2016 "On statement of the consideration order of e-petitions, addressed to the Cabinet of Ministries of Ukraine". 
Realization of the mechanism of e-consulting is provided by the resolution of the Cabinet of Ministries of Ukraine No. 996 of 03.11 .2010 "Order of consulting with publicity on questions of state policy formation and realization".

The tool of e-voting is for 12.08.2020 realized as a pilot project for forming public councils.

The analysis of mechanisms of support, development and realization of e-democracy tools allowed to reveal gaps, negatively influencing e-democracy development in whole.

The results of the analysis of this legislative base led to a conclusion that one of defects, restraining e-democracy development in Ukraine, is imperfection of the legal mechanism of resource support of e-tools development.

E-democracy tools development in the resource aspect is mainly provided for today by financing automation resources of state institutions and departments that in its turn doesn't favor the development of these tools, but only provides technological development of these resources.

This defect is in the absence of an integral idea of the state about the development strategy of e-democracy as an institution that must increase the total democratization level of Ukraine. The improvement of a series of e-democracy tools, adopted by the Cabinet of Ministries of Ukraine as the Plan of arrangements for realization of the development Conception of e-democracy contains an essential number of recommendations for a series of ministries and departments, but the obligation to allot costs for realizing these recommendations is not determined by law. In the best case the result of such situations is formed theoretical proposals for solving existing problems, but their practical realization becomes impossible because of lack of financing.

At the local level there is a problem of normative-legal support of these tools alongside with the problem of absence of their resource support. Thus, the development of e-democracy tools at the local level faces the problem of absence of a legislative base of the national level that must regulate their realization at the regional one. For today the way out of this situation is chosen by local administrations through accepting normative documents of the local level [9, 10].

At the same time, the problem of insufficient abilities and skills of power representatives and publicity is extremely important at the local level in the aspect of using and introducing e-democracy tools; absence of motivation for citizens to join consulting and discussions, including because of the essential level of distrust to power and democratic institutions.

According to the result of juxtaposition of e-democracy tools, fixed by law, and ones, realized by public organizations (Fig. 1) the author came to a conclusion that state authorities in first turn realize formalized, reproduced e-democracy tools as typical solutions of the tools, demonstrated the maximal effectiveness in the process of their implementation by public organizations. An approach, when the state tries to get out of the process of development and testing of e-democracy tools and resource support of these processes, leaving it to public organizations, is typical for Ukraine. At that the resource support of public initiatives is provided by grants of European partners. After successful introduction of a concrete tool by forces of public organizations, the acquired experience is realized as recommendations for the Government and Parliament by developing correspondent documents, forming the base of legislative acts.

For developing e-democracy, creating and implementing its tools, a series of public organizations created a coalition, named "E-democracy" This coalition includes an anti-corruption organization Transparency International, funds "Renaissance" and "Eastern Europe", public organizations "Reanimation reform package" and "E-democracy", representatives of the programs EGAP and TAPAS, "New country", Center of innovations development, Strategic group of consultants for supporting reforms in Ukraine (SAGSUR), the Ofice of effective regulation BRDO and suppliers of e-solutions, among which Helsi.me, iGov, ProZorro, YouControl.

\section{Shortcomings of the public administration of e-democracy tools}

Thus, the work separates the series of shortcomings, inherent to the legal mechanism of public administration of e-democracy tools implementation at the national and local levels, namely:

- imperfection of resource provision of the legal mechanism of e-democracy tools development;

- absence of an integral idea of the development strategy of e-democracy as an institution in the state; 
- predominance of e-services, automation development over development of tools of active involvement of citizens into participation in the public-political life of the country;

- insufficient level of digital and legal literacy of officials as to developing and introducing the legislative base in the sphere of e-democracy and its tools;

- absence of the normative-legal base of the national level for forming legal principles of creation, realization and development of e-democracy tools at the local level.

\section{Recommendations to the authorities}

The author has elaborated the following recommendations for authorities for improving the legal mechanism of public administration of e-democracy tools implementation:

- to elaborate and to adopt the development Strategy of information society in Ukraine for 2020-2025 and to define e-democracy as one of priority state policy directions;

- to elaborate and to adopt the National strategy of favoring civic society development in Ukraine for the period till 2025 as a legal background of e-democracy development in Ukraine;

- to elaborate the addition to the activity program of the Government, taking into account international experience and distinct formulation of tasks to the profile ministry in the sphere of e-democracy development as a part of digital society formation in Ukraine;

- to determine the necessity of e-democracy tools implementation and use as one of priorities of the National informatization program;

- to provide the legislative support of mechanisms of e-democracy tools implementation and development at both national and local levels by elaborating and adopting the e-democracy Strategy, based on the accumulated activity experience of central and local authorities;

- to provide the resource support of legal mechanisms of e-democracy tools realization and development by adopting the Program of arrangements on e-democracy Strategy realization;

- to develop effective mechanisms of financial support for public initiatives;

- to regulate the legislation in the sphere of e-democracy tools realization at the local level (e-appeals, petitions, consulting and so on);

- to develop the mechanism for implementing e-voting and also e-election process, e-referendums and e-plebiscites;

- to establish posts of officials, which competence includes e-democracy tools implementation and realization;

- to provide the legal and resource support of re-training power representatives in the sphere of e-democracy tools usage; explicative work among the population as to the expedience of e-democracy tools usage.

\section{Conclusions}

1. The totality of main normative-legal acts on problems of e-democracy tools development has been analyzed, structured and compared with basic European legislative acts.

2. The comparative analysis of e-democracy tools usage in Ukraine and EU and also their usage by public authorities and public organizations has been conducted.

3 . The defects, inherent to the national legal mechanism of public administration of e-democracy tools implementation at the national, regional and local levels have been separated.

4. The recommendations for authorities as to improvement of the existing legal mechanism of e-democracy tools realization have been substantiated.

Further studies will be directed on considering organizational mechanisms of public administration of e-democracy development in Ukraine.

\section{References}

[1] Kontseptsiia rozvytku elektronnoi demokratii v Ukraini (2017). Rozporiadzhennia Kabinetu Ministriv Ukrainy No. 797-r. 08.10.2017. Available at: https://zakon.rada.gov.ua/laws/show/797-2017- \%D1 \%80 Last accessed: 11.08.2020

[2] Holovni tsili Ministerstva tsyfrovoi transformatsii Ukrainy. Ofitsiinyi sait Ministerstva tsyfrovoi transformatsii Ukrainy. Available at: https://thedigital.gov.ua/ministry Last accessed: 10.08.2020 
[3] Pro zatverdzhennia Prohramy diialnosti (2020). Kabinetu Ministriv Ukrainy. red. postanova Kab. Ministriv Ukrainy No. 471. 12.06.2020. Available at: https://zakon.rada.gov.ua/laws/show/471-2020- \%D0 \%BF Last accessed: 09.08.2020

[4] Semenchenko, A. I., Serenok, A. O.; Semenchenko, A. I., Dreshpaka, V. M. (Eds.) (2017). Elektronne uriaduvannia ta elektronna demokratiia. Part 3: Elektronna demokratiia: osnovy ta stratehii realizatsii. Kyiv: FOP Moskalenko O. M., 84.

[5] Semenchenko, A. I., Serenok, A. O.; Semenchenko, A. I., Dreshpaka, V. M. (Eds.) (2017). Elektronne uriaduvannia ta elektronna demokratiia. Part 4: Publichna polityka ta upravlinnia rozvytkom informatsiinoho suspilstva ta elektronnoho uriaduvannia. Kyiv: FOP Moskalenko O. M., 80.

[6] Hrytsiak, N. V., Soloviov, S. H. (2015). Elektronna demokratiia. Kyiv: NADU, 66.

[7] Recommendation $\mathrm{CM} / \operatorname{Rec}(2009) 1$ of the Committee of Ministers to member states on electronic democracy (e-democracy) (2009). Available at: https://wcd.coe.int/ViewDoc.jsp?id=1410627 Last accessed: 12.08.2020

[8] Vykorystannia instrumentiv elektronnoi demokratii orhanamy derzhavnoi vlady ta mistsevoho samovriaduvannia. Derzhavna sluzhba statystyky. Available at: http://www.ukrstat.gov.ua/operativ/operativ2020/infs/vied_19.xls Last accessed: 03.08.2020

[9] Instrumenty hromadskoi uchasti u Lvovi (2020). Sait hromadskoi merezhi OPORA. Available at: https://www.oporaua.org/ news/samovriaduvannia/partysypatsiia/19770-instrumenti-gromadskoyi-uchasti-u-lvovi Last accessed: 12.08.2020

[10] Instrumenty uchasti v zhytti hromady (2020). Sait Vinnytskoi miskoi rady. Available at: https://www.vmr.gov.ua/Lists/Actual/ ShowNews.aspx?ID=1219 Last accessed: 12.08 .2020 